\title{
Article
}

\section{Covid-19 Pandemic and Food Waste: An Empirical Analysis}

\author{
Federica Di Marcantonio ${ }^{1}$, Edward Kyei Twum ${ }^{2}$ and Carlo Russo ${ }^{2, *}$ \\ 1 Joint Research Centre, European Commission, 41092 Seville, Spain; Federica.di-marcantonio@ec.europa.eu \\ 2 Department of Economics and Law, University of Cassino and Lazio Meridionale, 03043 Cassino, Italy; \\ edwardkyei.twum@unicas.it \\ * Correspondence: carlo.russo@unicas.it
}

Citation: Di Marcantonio, F.; Twum, E.K.; Russo, C. Covid-19 Pandemic and Food Waste: An Empirical Analysis. Agronomy 2021, 11, 1063. https://doi.org/10.3390/ agronomy11061063

Academic Editor: Gabrijel Ondrasek

Received: 9 April 2021

Accepted: 10 May 2021

Published: 25 May 2021

Publisher's Note: MDPI stays neutral with regard to jurisdictional claims in published maps and institutional affiliations.

Copyright: () 2021 by the authors. Licensee MDPI, Basel, Switzerland. This article is an open access article distributed under the terms and conditions of the Creative Commons Attribution (CC BY) license (https:// creativecommons.org/licenses/by/ $4.0 /)$.

\begin{abstract}
This paper investigates the impact of Covid-19 pandemic on food waste using an original dataset from 176 agrifood business operators in the European Union (EU). Our objective is to assess whether and why the pandemic crisis affected food waste level. Unlike previous studies that addressed the issue at a consumer level, our research focuses on pre-consumption waste covering stages of the agrifood supply chain from input suppliers to retailers. Considering the importance of waste reduction for the sustainability of food production, the study provides an insight into the ability of the agrifood supply chain to cope with a major shock and its resilience. A multinomial logit regression model is used to estimate the effect of Covid-19, testing whether the ability to innovate, the role in the supply chain, the magnitude of the shock and policy support were drivers of changes in food waste. We find that three main factors affect the change in a firm's food-waste level during the Covid-19 pandemic: The magnitude of the disruption of the sale channel, the firms' ability to adapt the business model to the new pandemic environment, and the adoption of public policies mitigating the lockdown effects. The first driver was associated with an increase in food waste, while the others were associated with a decrease.
\end{abstract}

Keywords: Covid-19; food waste; agrifood supply chain

\section{Introduction}

The Covid-19 pandemic had considerable effects on vital sectors of the world economy [1]. In the food sector, the Covid-19 pandemic has disrupted supply chains raising concerns on food security (e.g., [2-5]) and resilience to shocks (e.g., [6,7]). Nevertheless, the agrifood supply chains in the European Union (EU) responded to the Covid-19 pandemic disruption better than other sectors $[8,9]$.

This paper investigates the impact of Covid-19 pandemic on food waste in the EU agrifood chain. The topic is motivated by the importance of food waste as a key dimension of the agrifood system performance. Nearly one third of food is discarded every year from agrifood supply chains globally (approximately 1.3 billion tons) before reaching final consumers [10] with an annual cost of over 143 billion Euros in the EU alone [11]. Tackling food waste helps deal with food insecurity [12-15], preserves natural resources [10,16], and promotes sustainable practices in agrifood supply chains [14]. Food waste reduction is a policy objective, as well. The 2015 sustainable development goals (SDGs) targets reducing global food waste at every segment of agrifood supply chains, and food waste is part of the monitoring framework in EU Commission's plan for circular economy [17]. Investigating the effects of Covid-19 pandemic on food waste provides an important insight into the resilience of agrifood supply chains and its ability to preserve sustainability even when coping with systemic shocks.

An original dataset from 176 agrifood business operators in the EU was used to explain changes in food waste during the first Covid-19 lockdown. Our analysis moves from the fact that the Covid-19 pandemic has an indirect impact on food waste. Food waste is the result of a complex set of drivers, by affecting these drivers, the Covid-19 pandemic 
outbreak generates a variation (positive or negative) in the amount of waste. The goal of this paper is to identify and describe this process.

The main contribution of this paper to the existing literature is a supply chain approach To the best of our knowledge, studies assessing the impact of Covid-19 pandemic on food waste mainly concerned the consumer (e.g., [17-21]), with other actors and processes in the agrifood supply chain being rarely mentioned. The paper addresses this gap in the literature by providing an understanding of Covid-19 pandemic effect on food waste in pre-consumption stages of the agrifood supply chain (from input suppliers to retailers and services).

The remaining part of the paper is organized as follows: Section 1.1 provides a brief review of the literature on drivers of food waste in pre-consumption stages of the agrifood supply chain, from input suppliers to retailers and services. Section 2 debates the effects of Covid-19 pandemic on the drivers, illustrates the dataset, and presents the econometric model. Sections 3 and 4 report the results of the empirical investigation and a discussion of the findings, and Section 5 concludes.

\subsection{Pre-Consumption Food Waste Drivers}

Food waste refers to food discarded in agrifood supply chains from farm to fork [22,23]. For the purpose of this paper, we identify two types of waste: Pre-consumption waste and consumption-related waste. The former focuses on the interconnected processes and entities within agrifood supply chains, from input suppliers to retailers and services excluding the consumer (e.g., [24,25]), while the latter primarily focuses on the consumer (e.g., [26,27]). In our analysis of Covid-19 pandemic impact, we focus on pre-consumption waste alone.

In this section, we briefly review the literature on pre-consumption food-waste drivers that is instrumental to our investigation (for more exhaustive reviews, see $[10,12,28,29]$ ).

The existing literature proposed several classifications of pre-consumption food drivers; [10] identified financial, managerial, and technical factors; [29] grouped by technological, institutional, and social issues, and [12] classification was based on the effect of modernization on agrifood systems - where the focus was on economic growth, urbanization, industrialization, and globalization-, socio-demographic factors, and cultural factors. However, these classifications were ill-suited to our analysis of Covid-19 impact in the EU. In fact, they emphasize technical and development factors that can be considered as given in our analysis and may have a low explanatory power.

For the purpose of our research, we clustered pre-consumption food-waste drivers from the existing literature into five groups: Human capital, Infrastructures, Market, Public Action, and Environment (Table 1). Compared to the classifications in $[10,12,29]$, our taxonomy focuses on the origin and cause of the drivers rather than their nature. For example, technical factors were included into Human capital drivers (if failing to adopt a technology is due to mismanagement or lack of skills) and Market drivers (if the issue is due to imperfection in the credit market). Similarly, losses of edible food due to rejection for lack of conformity to quality standards were included into Public Action drivers (if the standards were imposed by public regulations) and Market drivers (if they were contractual arrangements). 
Table 1. Food waste drivers in agrifood supply chains.

\begin{tabular}{|c|c|c|}
\hline Reference & Author/s & Example/s of Food Waste Drivers \\
\hline \multicolumn{3}{|c|}{ Human Capital Drivers } \\
\hline$[10,29,30]$ & $\begin{array}{l}\text { Canali et al. (2017), Raak et al. (2017), Gustavsson } \\
\text { et al. } \\
\text { (2011) }\end{array}$ & Overproduction \\
\hline$[31,32]$ & Silvennoinen et al. (2019), Bilska et al. (2020) & Over-preparation \\
\hline [28] & Parfitt et al. (2010) & $\begin{array}{c}\text { Premature harvesting, poor harvesting } \\
\text { technique, and } \\
\text { process loss, contamination in process, } \\
\text { inappropriate } \\
\text { packaging }\end{array}$ \\
\hline [33] & FAO (2019) & Labor unavailability/cost \\
\hline [34] & Gunders (2012) & Unskilled Labor \\
\hline$[12,35]$ & Thyberg and Tonjes (2016), Mena et al. (2011) & Poor forecasting \\
\hline$[28,36]$ & Parfitt et al. (2010), Kantor et al. (1997) & Poor handling \\
\hline \multicolumn{3}{|l|}{ Market Drivers } \\
\hline$[25,34]$ & Johnson et al. (2019), Gunders (2012) & Low prices \\
\hline [28] & Partiff et al. (2010) & Lack of capital, credit constraint \\
\hline [32] & Bilska et al. (2020) & Excessive ordering \\
\hline \multicolumn{3}{|c|}{ Public Action Drivers } \\
\hline [37] & Griffin et al. (2009) & Subsidies \\
\hline$[29,38]$ & Waarts et al. (2011), Canali et al. (2017) & $\begin{array}{c}\text { Food safety and hygiene regulations, Import } \\
\text { controls }\end{array}$ \\
\hline \multicolumn{3}{|c|}{ Infrastructure Drivers } \\
\hline$[10,12]$ & Thyberg and Tonjes (2016), Gustavsson et al. (2011) & Inadequate transport infrastructure \\
\hline$[10,29,39]$ & $\begin{array}{l}\text { Canali et al. (2017), Gustavsson et al. (2011), Adam } \\
\text { (2015) }\end{array}$ & Lack or insufficient storage facilities \\
\hline $\begin{array}{c}{[12,28]} \\
{[10]}\end{array}$ & $\begin{array}{c}\text { Parfitt et al. (2010), Thyberg and Tonjes (2016), } \\
\text { Gustavsson et al. (2011) }\end{array}$ & $\begin{array}{l}\text { Poor storage } \\
\text { Lack of processing facilities }\end{array}$ \\
\hline
\end{tabular}

Environmental Drivers

$[22,24,28]$

[33]
Parfitt et al. (2010), Aulakh et al. (2013), Kulikovskaja and Aschemann-Witzel (2017) FAO (2019)
Pests attack and diseases

Excess rainfall or lack of rainfall

Source: Authors' elaboration.

Human capital drivers capture managerial decisions and technical skills that result in food waste along agrifood supply chains. This category includes several factors such as the effects of mismanagement, wrong production decisions (e.g., [10,28,30]) including overproduction $[10,29,30]$, over-preparation [31,32], and premature harvest [28]. Lack of managerial and agronomic skills [10], labor availability/or cost [33], and worker skills [34] contribute to food waste as well since they can result in the use of poor techniques in harvesting, product preparation or handling $[28,36]$. Error in forecasting stochastic demand or inability of sharing accurate information $[35,40]$ may lead to wrong production decisions [12,35], overstocking [12], and ultimately to food waste. Food waste caused by bad managerial decisions and poor technical skills may also come in the form of poor practices at the farm level (resulting in food left to remain on the field, food that gets damaged during harvesting, food eaten by pests and birds on the field, food ploughed into soil [12,28]), manufacturing level (e.g., food contaminated or damaged in the production process [12]) or in services (e.g., kitchen waste, customer plate waste, and buffet leftovers [31]).

Market food waste drivers capture the buyer-seller interactions along the agrifood supply chain ultimately resulting in food waste. Farmers may decide to restrain from harvesting and leave food in the field if the market price is too low [25,34]. Thus, an intersection of human capital drivers and market drivers can cause an increase in food waste in an agrifood supply chain. Imposing stringent food quality standards may also 
be associated with an increase in food waste, as firms and growers may fail to meet the requirements [25,34,39]. This group includes the effects of imperfection on capital markets, since the lack of capital and credit constraints may lead to food waste [41]. Excessive ordering contributes to the amount of food waste at the food service stage in agrifood supply chains [32].

Several contributions in the literature remarked the effects of public action on food waste (e.g., [29,38,42]). Examples include tax schemes or subsidies leading to overproduction [37] or regulations requiring discarded food not to be given to animals as feed [38,43]. In general, strict food safety and quality regulations may lead to waste if they lead to discarding edible food $[29,38,43]$, even though improved quality controls can prevent losses [43,44]. Import controls may lead to food waste as well $[29,38]$ if it takes too long to control imported food [38]. The longer import controls take, the nearer food gets closer to their 'use by' or 'date before' consumption. As a consequence, food may expire before reaching final consumers.

Infrastructural issues contribute to food waste in agrifood supply chains. They include inadequate transport infrastructure [10,12,36], lack or insufficient storage facilities [10,29,39], poor storage [12,28], and lack of processing facilities [10]. Although these drivers are identified as predominant causes of food waste in developing countries [10], business operators in developed countries may consider this for international trade purposes [29].

Environmental drivers include natural factors generating food waste directly. These drivers include animal and crop diseases and pests, extreme weather events destroying crops, and climate change affecting agrifood production [45]. Furthermore, production provisions to curb the effect of unexpected environmental event may result in overproduction of needed food quantity, thus contributing to food waste, with an interaction between environmental and human capital drivers [10].

The Covid-19 pandemic was not included in environmental food waste drivers since it is a human disease with no immediate effects on crops or animals [3]. Unlike other diseases (such as bird or swine flu) that cause a loss of food directly, the waste happens as a consequence of demand shocks or production and logistic disruption of the agrifood supply chain. The Covid-19 pandemic determines changes in the main food-waste drivers and consequently affects food waste indirectly. In Section 2, we elaborate on this point and illustrate the empirical model.

\section{Materials and Methods}

\subsection{The Impact of Covid-19 Pandemic on Drivers of Food-Waste}

The Covid-19 pandemic can be considered as a systemic shock to the entire agrifood supply chain affecting the food waste drivers. The conceptual framework is summarized in Figure 1.

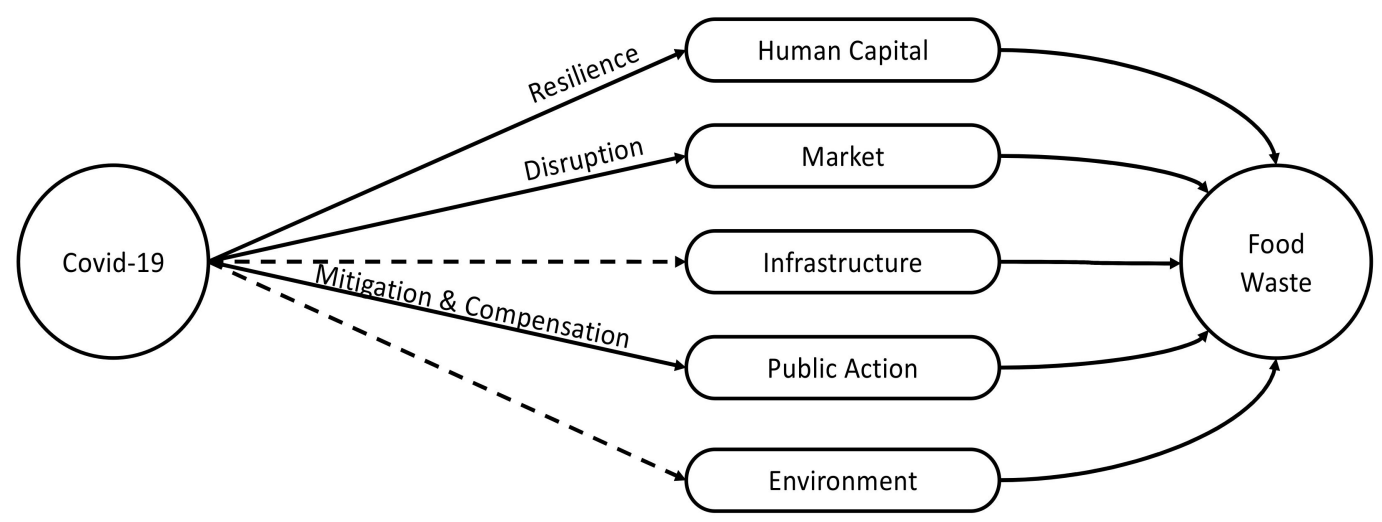

Figure 1. The indirect impact of Covid-19 pandemic on food waste. 
Figure 1 illustrates indirect effects of Covid-19 pandemic on the pre-consumption foodwaste drivers. In our analysis, we assumed that the pandemic did not affect environmental and infrastructural drivers. Although effects might arise in the long run, the short time horizon of the investigation did not allow us to capture them. Thus, our analysis focused on the Market, Human Capital, and Public Action drivers.

The Covid-19 pandemic resulted in a disruption in the agrifood supply chains both on the demand and the supply side [3,6]. On the supply side, restrictions to movement of workers and goods affected production and the insurgence of contamination events induced sudden stops that were particularly severe in highly concentrated industries. These consequences affected the buyer-seller interaction along the agrifood supply chains, increasing risk, volatility, and the probability of trade failure. The containment measures, such as lockdown, resulted in dramatic changes in food demand such as panic buying and hoarding, diet change and drop in the demand for food services (e.g., [46]). Based on the literature on market drivers, we hypothesize that firms that faced trade disruption due to the effects of Covid-19 pandemic, on average, were more likely to incur in more food waste compared to the pre-pandemic level. On the other hand, panic buying and stockpiling consumer behavior may determine a reduction of food waste at retail stores in the short run. As a consequence, we hypothesize that retailers may experience a reduction of food waste during lockdown.

The change in the economic and social environment during the Covid-19 pandemic was a challenge for several agrifood businesses [6]. In this regard, we expect that human capital may favor the adoption of resilience strategies. We hypothesize that firms that were unable to change their operations to meet the crisis were also associated with worse performance in terms of food waste than those who were able to innovate.

The pandemic elicited a strong response from policy makers [47]. An intense debate originated on the optimal balance between protection of public health and business support during the Covid-19 pandemic crisis. In the attempt to cope with the emergency, several measures have been adopted to contain the virus and protect the economy at the same time. The lockdown was accompanied by specific actions to compensate firms' financial losses and mitigate the impact on vital sectors of the economy. The intense public action affected the institutional environment, which is one of the food waste main drivers. We expect that public support was associated with a better performance in terms of food waste.

The conceptual framework provided several testable hypotheses on the effect of the Covid-19 pandemic on food waste. Table 2 summarizes the testable hypothesis. For an easy reference, we defined a better (worse) relative performance in terms of food waste (RFWP) of a group of firms as the higher (lower) likelihood of experiencing a reduction of food waste and/or the lower (higher) likelihood of experiencing a food waste increase with respect to a control group.

\subsection{The Empirical Investigation}

An econometric model was used to test the hypotheses in Table 2. Based on the conceptual framework, the model was specified as follows:

$$
E\left(\Delta F W_{i}\right)=f\left(\Delta \boldsymbol{M}_{i}, \Delta H C_{i}, \Delta \boldsymbol{P} A_{i}, \boldsymbol{Z} \mid \boldsymbol{\beta}\right)
$$

where $E\left(\Delta F W_{i}\right)$ is the expected change in food waste during the lockdown period for firm $i, \Delta \boldsymbol{M}_{i}, \Delta \boldsymbol{H} \boldsymbol{C}_{i}, \Delta \boldsymbol{P} \boldsymbol{A}_{\boldsymbol{i}}$ are vectors of variables measuring the effect of Covid-19 pandemic on the Market, Human Capital, and Public Action food-waste drivers, respectively; $\boldsymbol{Z}$ is a set of additional explanatory variables and $\beta$ is a vector of parameters to be estimated. The potential problem of multicollinearity was tested with the collin comand in Stata, which return a VIF $<10$, which was considered acceptable [48]. 
Table 2. Testable hypotheses on relative food waste performance (RFWP) during the Covid-19 lockdown period.

$\begin{array}{ll}\begin{array}{l}\text { Hypothesis } 1 \\ \text { (trade disruption }\end{array} & \mathrm{H}_{0} \text { : Trade disruption during lockdown did not determine a worse RFWP. } \\ \text { effect) } & \mathrm{H}_{1} \text { : Firms that experienced trade disruption during lockdown, on } \\ \text { average, had a worse RFWP than others. }\end{array}$

$\mathrm{H}_{0}$ : The expected RFWP of retailers is not different from the expected

Hypothesis 2 RFWP of firms in other stages of the agrifood supply chain.

(retail effect) $\mathrm{H}_{1}$ : H1: On average, better Retailers' RFWP as compared to other firms during lockdown.

$\begin{array}{ll}\text { Hypothesis } 3 & \text { during lockdown. } \\ \text { (innovation effect) } & \begin{array}{l}\mathrm{H}_{1} \text { : Innovative firms, on average, had better RFWP than others } \\ \text { during lockdown. }\end{array}\end{array}$

$\mathrm{H}_{0}$ : Business innovation did not determine better RFWP during lockdown. during lockdown.

Hypothesis 4 (policy effect)

$\mathrm{H}_{0}$ : Public intervention did not enhance RFWP.

$\mathrm{H}_{1}$ : Public intervention enhanced RFWP.

Since the dependent variable was categorical, a multinomial logistic regression model was used to predict the probabilities of category membership on a dependent variable based on multiple independent variables [49]. Multinomial logistic regression is a simple extension of binary logistic regression that allows more than two categories of the dependent or outcome variable [49]. We used the maximum likelihood estimation to evaluate the probability of categorical membership.

The log odds of occurrence of food waste with respect to the reference category (here, the first) is described as follows:

$$
l=\log _{e}\left(\frac{y_{i}=k}{y_{i}=1}\right)=\beta_{0}+\beta_{1} x_{1}+\beta_{2} x_{2}+\ldots,+\beta_{k} x_{k}+\epsilon_{i}
$$

where $l$ is the log odds, $\beta_{j}$ is the $j^{\text {th }}$ coefficient of the equation, and $\epsilon_{i}$ is the error term and the $x^{\prime}$ s are the variables in the vectors $\Delta M, \Delta H C, \Delta \boldsymbol{P A}$ and $Z$. The interpretation of the $\beta_{j}$ coefficients is not always straightforward since, unlike binary models a positive sign on a coefficient in an MLM does not necessarily mean that an increase in the independent variable corresponds to an increase in the probability of choosing a particular mode of entry $[50,51]$. Furthermore, the relationship between the explanatory variables and the probability of a given choice outcome is nonlinear and may even change sign across the distribution of a single predictor. Thus, based on Equation (1), the marginal effects of the model are also calculated and presented. The marginal effects are defined as the slope of the prediction function at a given value of the explanatory variable and thus inform us about the change in predicted probabilities due to a change in a particular predictor [52]. This has made authors argue that if one wishes to draw valid conclusions about the direction and magnitude of the relation between an independent and dependent variable in an MLM, one must calculate marginal effects [52].

\subsection{Dataset}

The data for the estimation of Equation (2) were obtained from an existing dataset that was collected by the Joint Research Centre (JRC) of the European Commission. To understand the impact of Covid-19 pandemic on agrifood business operators, JRC launched and administered an online questionnaire across operators in the EU agrifood supply chains. A non-probabilistic sampling design was used. While random sampling would clearly 
have been preferable, it was not possible to obtain contact records for the sampling frame due to the lack of available research panels database for farmers or other business operators at the EU level. A limited number of contacts were however retrieved through available online panel databases especially for food services providers and business companies registered in these online panels. The use of a non-probabilistic sample does not guarantee a national representativeness and does not provide reliable prevalence data. However, basic descriptive analyses and explorations of potential associations can be appropriate in such surveys [53] and were used in a large part of Covid-19 pandemic studies so far (e.g., $[54,55])$. For the recruitment, survey weblinks were shared through social media, key EU stakeholders, associations, public officers, and umbrella organizations across EU member states.

In total, invitations were sent to 2466 business operators and almost 200 organizations, stakeholders, and public officers for dissemination. Two hundred and eighty questionnaires were collected from business operators across EU member states. Then, 104 incomplete questionnaires were discarded and the final sample size was 176 valid observations.

The study questionnaire consisted of five different sections: (i) General, where information on the characteristics of the businesses (i.e., headquarter, sector, stage in the agrifood supply chain, turnover, etc.), and activities were collected; (ii) impact, where operators were invited to provide information on the impact of Covid-19 pandemic outbreak on different areas (input, production, sale, labor, logistics, and financial resources); (iii) measures, describing the main actions that firms took to cope with the effects of the pandemic (including the access to public support); (iv) future perspective and preparedness; and (v) a final small section for collecting individual information of participants. The questionnaire included Likert scales, single and multiple choice, and open-ended questions. It took approximately thirty minutes to complete and respondents were not compensated.

The questionnaire was first developed in English, then translated into all EU languages using professional translators, and piloted with five participants to examine feasibility, clarity, errors, and other issues. It was hosted on the European Commission online survey platform and launched on 14 July 2020 and closed 15 January 2021.

The results of the dataset were used to measure the variables in Equation (2). The dependent variable $\Delta F W_{i}$, was obtained by combining the response from a five-scale question on the level of food waste as compared to the situation before the Covid-19 pandemic. Due to the limited number of responses in the extreme categories, the variables were recoded into three categories ranging from 'No change/Not applicable' $(=1)$, 'Increase $1-50 \%$ ' (=2), 'Decrease 1-50\%' (=3) (Table S1).

Given the high number of items in the questionnaire compared to the number of observations, a selection of the model variables was necessary. The independent variables were chosen using a three-step procedure. First, each variable was included in one of the vectors $\Delta M_{i}, \Delta H C_{i}, \Delta P A_{i}$ or $Z$ (or discarded if irrelevant). Then, they were selected by initial testing through univariate analysis and those showing a significant association with the dependent variable $(p<0.05)$ were entered into the full model and backward stepwise regression analysis was then used to select the final significant variable set. Table 3 reports the model variables. For simplicity, the subscript $i$ is dropped henceforth. 
Table 3. Sample characteristics $(n=176)$.

\begin{tabular}{|c|c|c|c|}
\hline \multirow[t]{2}{*}{ Variables } & \multirow[t]{2}{*}{ Description } & \multicolumn{2}{|c|}{ Frequencies } \\
\hline & & $n$. & $\%$ \\
\hline \multirow{5}{*}{$\Delta \mathrm{FW}$} & Dependent variable & & \\
\hline & Change in food waste during lockdown & & \\
\hline & No change/Not applicable & 113 & 64.20 \\
\hline & Increase & 13 & 7.39 \\
\hline & Decrease & 50 & 28.41 \\
\hline$D M$ & Market Drivers & & \\
\hline \multirow[t]{6}{*}{ DPB } & More delayed payments from buyer(s) & & \\
\hline & From 1 meaning not changed at all & 43 & 24.43 \\
\hline & $2 / 5$ & 15 & 8.52 \\
\hline & $3 / 5$ & 46 & 26.14 \\
\hline & $4 / 5$ & 39 & 22.16 \\
\hline & To 5 meaning changed at large extent & 33 & 18.75 \\
\hline \multirow[t]{6}{*}{ DPS } & More delayed payments to input provider(s) & & \\
\hline & From 1 meaning not changed at all & 83 & 47.16 \\
\hline & $2 / 5$ & 9 & 5.11 \\
\hline & $3 / 5$ & 51 & 28.98 \\
\hline & $4 / 5$ & 20 & 11.36 \\
\hline & To 5 meaning changed at large extent & 13 & 7.39 \\
\hline $\mathrm{DHC}$ & Human Capital Drivers & & \\
\hline EOL & Enhance/develop online selling $(\mathrm{EOL}=1)$ & 58 & 32.95 \\
\hline SAS & Search for alternative suppliers $($ SAS $=1$ ) & 58 & 32.95 \\
\hline $\mathrm{SAB}$ & Search for alternative buyers $(\mathrm{SAB}=1)$ & 85 & 48.30 \\
\hline LAB & Add labels safety rules $(\mathrm{LAB}=1)$ & 6 & 3.41 \\
\hline$D R$ & Regulation Drivers & & \\
\hline UNB & Self-employed unemployment benefits $(\mathrm{UNB}=1)$ & 11 & 6.25 \\
\hline DSC & Delayed social security contributions (DSC $=1$ ) & 42 & 23.86 \\
\hline FCM & Facilitation of cross border mobility $(\mathrm{FCM}=1)$ & 16 & 9.09 \\
\hline OLP & Online job platform created by authorities (OLP $=$ & 8 & 4.55 \\
\hline$Z$ & Other Explanatory Variables & & \\
\hline \multirow{6}{*}{ STA } & Stage in the chain: & & \\
\hline & Input providers & 9 & 5.11 \\
\hline & Farmers, Farmer association & 70 & 39.77 \\
\hline & Manufacturers & 76 & 43.18 \\
\hline & Intermediaries & 10 & 5.68 \\
\hline & Retailers, Food Services & 11 & 6.25 \\
\hline ANP & Animal and animal related production $(\mathrm{ANP}=1)$ & 42 & 23.86 \\
\hline
\end{tabular}

Source: Authors' elaboration based on the JRC online survey.

\section{Results}

\subsection{Descriptive Statistics}

The sample descriptive statistics were provided in Table 3. The farmers and farmer association (including POs) comprised 70 (40\%) of the study sample. In addition, $43 \%$ were manufacturers, $6 \%$ intermediaries, $6 \%$ retailers or food services, and $5 \%$ input providers. Less than one-fourth of the study sample operates in the livestock and animal product sector.

The Covid-19 pandemic outbreak affected production sustainability. In addition, $7 \%$ of respondent reported that food waste increased as compared to the pre-Covid-19 pandemic period, while about twice as much experienced a reduction in food waste in the same period.

Almost half of participants reported a more delayed payments from buyers during the Covid-19 pandemic as compared to the pre-pandemic situation. The findings show that during the lockdown, participants implemented different mitigation strategies to cope with the supply disruption. In particular, 33\% of participants looked for alternative suppliers, while $48 \%$ switched to alternative buyers. Similarly, 33\% of them explored different selling channels such as an online sale, while the share of operators that add labels referring 
to compliance to Covid-19 pandemic safety rules account for 3\%. The label refers to a voluntary initiative by agrifood firms at early stages of the Covid-19 pandemic outbreak. Firms used to guarantee consumers compliance with strict hygiene practices at all stages of the supply chain, at a time when the way of transmission/infection of Covid-19 was not clear (and concerns were spreading that food related contagion was possible).

In response to the Covid-19 pandemic, the government intervened by implementing a wide set of measures to support operators in different sectors. These interventions policies, while heterogeneous across countries and regions, all aim to make the agrifood supply chain resilient to the Covid-19 pandemic outbreak. From the results, we observed that $6 \%$ of the study sample benefit from unemployment economic support, $24 \%$ from delayed deadline for social security contributions, $9 \%$ from facilitation of cross border mobility, and $5 \%$ from an online job platform created by authorities.

\subsection{Regression Results}

Table 4 reports the regression results. Looking at the model fit statistics, we observe that the likelihood ratio (LR) test of our model is significant $\left(p<0.001, R^{2}=0.272\right)$, meaning that at least a subset of the predictors has non-zero effects.

Table 4. Regression results.

\begin{tabular}{|c|c|c|c|c|c|c|c|c|c|c|}
\hline \multirow{2}{*}{$\begin{array}{l}\text { Var. } \\
D M\end{array}$} & \multicolumn{4}{|c|}{ Coefficients } & \multicolumn{6}{|c|}{ Marginal Effects } \\
\hline & \multicolumn{2}{|l|}{ Increase } & \multicolumn{2}{|l|}{ Decrease } & $\begin{array}{c}\text { No } \\
\text { Change }\end{array}$ & \multicolumn{3}{|c|}{ Increase } & \multicolumn{2}{|l|}{ Decrease } \\
\hline DPB & 16.26 & $* * *$ & 0.971 & & -0.66 & $* * *$ & 0.94 & $* * *$ & -0.28 & \\
\hline & $(0.63)$ & & $(0.74)$ & & $(0.18)$ & & $(0.22)$ & & $(0.15)$ & \\
\hline DPS & 0.34 & & 0.40 & & -0.059 & & 0.01 & & 0.05 & \\
\hline & $(0.69)$ & & $(0.50)$ & & $(0.07)$ & & $(0.04)$ & & $(0.07)$ & \\
\hline \multicolumn{11}{|l|}{ DHC } \\
\hline \multirow[t]{2}{*}{ EOL } & 1.08 & & 1.82 & $* * *$ & -0.26 & $* * *$ & 0.017 & & 0.24 & $* * *$ \\
\hline & $(0.65)$ & & $(0.48)$ & & $(0.06)$ & & $(0.03)$ & & $(0.05)$ & \\
\hline \multirow[t]{2}{*}{ SAS } & -0.01 & & 0.95 & * & -0.11 & & -0.025 & & 0.14 & $*$ \\
\hline & $(0.74)$ & & $(0.47)$ & & $(0.06)$ & & $(0.04)$ & & $(0.06)$ & \\
\hline \multirow[t]{2}{*}{ SAB } & 0.78 & & 0.77 & & -0.12 & & 0.026 & & 0.09 & \\
\hline & $(0.85)$ & & $(0.51)$ & & $(0.07)$ & & $(0.05)$ & & $(0.07)$ & \\
\hline \multirow[t]{2}{*}{ LAB } & -15.36 & $* * *$ & 0.61 & & 0.44 & * & -0.93 & $* * *$ & 0.49 & $* *$ \\
\hline & $(1.11)$ & & $(0.92)$ & & $(0.20)$ & & $(0.21)$ & & $(0.16)$ & \\
\hline \multicolumn{11}{|l|}{$D R$} \\
\hline \multirow[t]{2}{*}{ UNB } & -15.70 & $* * *$ & 0.14 & & 0.51 & * & -0.93 & $* * *$ & 0.42 & $* *$ \\
\hline & $(1.61)$ & & $(0.91)$ & & $(0.21)$ & & $(0.23)$ & & $(0.16)$ & \\
\hline \multirow[t]{2}{*}{ DSC } & 1.82 & $* *$ & 1.08 & * & -0.19 & $* *$ & 0.08 & * & 0.11 & \\
\hline & $(0.66)$ & & $(0.54)$ & & $(0.07)$ & & $(0.04)$ & & $(0.07)$ & \\
\hline \multirow[t]{2}{*}{ FCM } & -15.83 & $* * *$ & 0.71 & & 0.45 & * & -0.96 & $* * *$ & 0.51 & $* * *$ \\
\hline & $(0.74)$ & & $(0.73)$ & & (0.19) & & $(0.22)$ & & $(0.15)$ & \\
\hline \multirow[t]{2}{*}{ OLP } & -15.93 & $* * *$ & -2.13 & * & 0.79 & $* * *$ & -0.89 & $* * *$ & 0.10 & \\
\hline & $(1.37)$ & & (1.07) & & $(0.19)$ & & $(0.22)$ & & $(0.18)$ & \\
\hline \multicolumn{11}{|l|}{$Z$} \\
\hline \multicolumn{11}{|l|}{ STA } \\
\hline \multirow{2}{*}{ Input prov. } & -0.40 & & -2.78 & & 0.33 & & 0.10 & & -0.44 & $*$ \\
\hline & $(1.57)$ & & (1.61) & & $(0.19)$ & & $(0.14)$ & & $(0.21)$ & \\
\hline \multirow[t]{2}{*}{ Farmers } & -1.68 & & -1.97 & * & 0.31 & $* *$ & -0.03 & & -0.28 & \\
\hline & $(1.37)$ & & $(0.85)$ & & $(0.12)$ & & $(0.09)$ & & $(0.15)$ & \\
\hline \multirow{2}{*}{ Manufact. } & -1.62 & & -2.40 & $* *$ & 0.37 & $* *$ & -0.01 & & -0.35 & $*$ \\
\hline & $(1.37)$ & & $(0.89)$ & & $(0.12)$ & & $(0.09)$ & & $(0.16)$ & \\
\hline
\end{tabular}


Table 4. Cont.

\begin{tabular}{|c|c|c|c|c|c|c|c|c|c|}
\hline \multirow[b]{2}{*}{ Var. } & \multicolumn{4}{|c|}{ Coefficients } & \multicolumn{5}{|c|}{ Marginal Effects } \\
\hline & Increase & & Decrease & & $\begin{array}{c}\text { No } \\
\text { Change }\end{array}$ & & Increase & Decrease & \\
\hline Intermed. & $\begin{array}{l}-1.68 \\
(2.35)\end{array}$ & & $\begin{array}{l}-3.43 \\
(1.27)\end{array}$ & $* *$ & $\begin{array}{c}0.47 \\
(0.16)\end{array}$ & $* *$ & $\begin{array}{c}0.00 \\
(0.16)\end{array}$ & $\begin{array}{l}-0.47 \\
(0.16)\end{array}$ & ** \\
\hline ANP & $\begin{array}{c}0.45 \\
(0.91)\end{array}$ & & $\begin{array}{c}0.78 \\
(0.57)\end{array}$ & & $\begin{array}{l}-0.11 \\
(0.08)\end{array}$ & & $\begin{array}{c}0.00 \\
(0.05)\end{array}$ & $\begin{array}{c}0.10 \\
(0.08)\end{array}$ & \\
\hline Constant & $\begin{array}{c}-17.98 \\
(0.97)\end{array}$ & $* * *$ & $\begin{array}{l}-1.67 \\
(0.93)\end{array}$ & & & & & & \\
\hline $\begin{array}{c}n \\
\text { Pseudo }\end{array}$ & $R^{2}$ & & $\begin{array}{l}176 \\
0.27\end{array}$ & & & & & & \\
\hline
\end{tabular}

Results showed that the Covid-19 pandemic impact on food waste may differ along the food chain. Farmers and farmer organizations, manufactures, and intermediary traders were less likely to decrease food waste compared to retailers. In addition, the marginal effect results indicated that the probability of decreasing food waste declined in the downstream stages of the food chain. The data did not support the hypothesis of a difference between firms in animal production and other firms.

The likelihood of having an increase in food waste during the lockdown was positively associated with delays in buyer's payments (DPB) and delays in social security contribution (DSC). The probability decreased if the firms adopted labels referring to compliance to Covid-19 pandemic safety rules and benefited from public support measures such as unemployment benefits for self-employed workers (UNB), facilitation of cross border mobility (FCM) or public online job platforms (OLP).

The probability of having a food waste reduction was positively associated with enhanced online selling (EOL), adoption of Covid-19 pandemic compliance labels (LAB), facilitation of cross-border mobility (FCM), and benefits for self-employed workers (UNB).

\section{Discussion}

The econometric model estimated the conditional probability of having a change in food waste given a set of explanatory variables. We found evidence of opposite trends in the agrifood supply chain. The descriptive statistics in Table 3 showed that there was a reduction of pre-consumption food waste during the lockdown period in $8 \%$ of cases and an increase in $16 \%$ of cases. This result is consistent with the findings of Roe et al. [18] regarding post-consumption waste. The econometric model validated this finding for pre-consumption waste, as well. Noticeably, the determinants of food waste increase differed from the determinants of food waste decrease. In particular, human capital and mitigation policies were associated with a decrease in food waste, while market drivers and compensation policies were associated with an increase in food waste.

In our econometric estimates, the market drivers (measured by the variable $D P B$ ) were strongly associated with an increase in food waste: The estimated marginal effect is 0.94 (Table 4). The result allows us to reject the null hypothesis in Hypothesis 1 (Table 2). It can be interpreted as a sign of agrifood firms' difficulties to adjust to disruptions of sale channels. The finding is consistent with the study by Johnson et al. [25] who found that the lack of buyers and low prices were associated with food waste. The quality of management and human capital were key factors driving the reduction of food waste during the observed period. Firms that were able to adapt their strategies to the new environment were more likely to improve their performance. The development of online sale channels was associated with a reduction of food waste. Firms boosting their online business during the lockdown increased by $24 \%$ their probability to decrease food waste (Table 4). 
Similarly, firms that implemented labels referring to compliance to Covid-19 pandemic safety rules were more likely to experience a decrease in food waste and less likely to increase it than others. This variable was associated with the firms' ability to adapt to the pandemic business environment. The label was an attempt to turn a compliance cost into a commercial advantage through product differentiation. This result confirmed that flexibility in the business model was a key driver to food waste reduction during the lockdown period. The results about online trade and the use of labels allow us to reject the null hypothesis in Hypothesis 3 (Table 2) and support the conclusion that the ability to innovate during lockdown determined a reduction of food waste.

We found no statistical evidence that the search for alternative buyers or suppliers affected food waste (Table 4). The finding was not expected given the strong association of delayed buyers' payment with the dependent variable. The result can be explained with the systemic nature of the shock, affecting the entire agrifood supply chain. In this case, simply replacing trade partners might not be sufficient to solve the problem.

The analysis of the marginal effects of the proxy variables for human capital suggested that flexibility in the business model was more important than flexibility in operations. The result was consistent with literature assessing that the ability to forecast demand and to adjust production accordingly is a key driver of food waste reduction [10,35]. In the case of Covid-19 pandemic, the magnitude of the shock required a restructuring of the entire business, while small changes were ineffective in contrasting food waste.

Policy support impacted on food waste (Hypothesis 4 in Table 2). Mitigation measures (facilitation of cross border mobility and creation of online job platforms) were unambiguously associated with a lower probability of increasing food waste. Facilitation of cross border mobility had a positive marginal effect on the probability of reducing food waste. A measure mitigating the disruptions due to the pandemic crisis is associated with a reduction of waste.

Instead, measures that merely compensated the damages from the pandemic, had an unclear effect on food waste. Unemployment benefits (UNB) were associated to an improvement in food waste performance, with a reduction in the probability of having an increase in the dependent variable and an increase in the probability of reducing waste. Delayed social security payments had a limited positive marginal effect on the probability of increasing food waste. In both cases, the purpose of the measure was to alleviate the financial impact of the Covid-19 pandemic crisis, providing additional benefits or delaying costs. These measures did not concern the drivers of food waste and did not favor a restructuring of the business. As a consequence, they did not support a transition towards business models with less waste.

The model supported the hypothesis that the Covid-19 pandemic affected food waste differently at the various stages of the agrifood supply chain. This result was expected and consistent with the previous literature [28]. Manufacturers, intermediaries, and input providers were found to be less likely to achieve a decrease in food waste and more likely to have no changes than retailers and food service (the reference category). These results allow us to reject the null hypothesis in Hypothesis 1 (Table 2). Although further research is needed to explain these results, a tentative justification for the outcome might be found in the classical shock transmission theory (e.g., [56]). According to this theory, the consequences of a shock are borne by the least elastic (less flexible) firms. Downstream firms such as supermarkets have a flexible procurement system and are able to adjust orders quickly, limiting the waste due to demand shocks. Upstream firms such as manufacturers, instead, might be less flexible in adjusting production lines. In this regard, it must be noticed that farmers did not register an increase in food waste despite their inelastic supply since the lockdown period, generally, happened before the harvest season (the lockdown period differed across the EU Member States, however, in general it took place during late winter and spring 2020). 


\section{Conclusions}

The empirical analysis confirmed the disruptive impact of Covid-19 pandemic event on the agrifood supply chain. In our investigation, we focused on the issue of preconsumption food waste and we found that the Covid-19 pandemic was a crisis in the etymological meaning of decision or decision point. Facing an unforeseen and unprecedented shock, firms had to decide whether to innovate their business model or to focus on damage control and wait for the pandemic to pass. The model result suggested that firms that were able to adjust their business model were also able to enhance their production efficiency reducing food waste. This finding is consistent with the previous literature on the effect of the Covid-19 pandemic on post-consumption waste [18]. From this perspective, the Covid-19 pandemic was a critical threat for agrifood firms but also an opportunity to re-assess their business strategy.

Government intervention can mitigate the effect of Covid-19 pandemic on food waste. However, the effectiveness depends on the objective of the policy. When the measures aimed at favoring innovation (such as the use of online platforms) or to mitigate the negative shock (such as favoring labor mobility), we found an association with food waste reduction. Instead, pure restoration measures (such as payments delays) had unclear effect. This finding stresses the importance of the public policy as an innovation incentive in times of crisis. When it facilitates the transition towards new business models, it can trigger a reduction of waste even during systemic shocks.

In general, the empirical model concluded that the impact of Covid-19 pandemic on food waste depended on the strategies of firms and governments. Business innovation were associated with reduction (or not increase) of food waste, while the absence of innovation left firms exposed to the consequences of the shock. These findings can be interpreted according to the literature about resilience (e.g., [57]). When facing a shock, firms may react with a conservative approach (bouncing back) trying to preserve the current activity or use the challenge for non-linear innovation in the business model (bouncing forward). From this perspective, the impact of Covid-19 pandemic on food waste depended on this strategic choice.

Our study was subject to several limitations. Data availability was a key constraint. The limited number of observations and the categorical nature of the data did not allow for a quantitative evaluation of food waste. Relying on respondents' subjective assessments of both dependent and explanatory variables may have induced an error of measurement that was difficult to qualify. Moreover, the small sample size did not allow for separated regressions for specific stages of the supply chain, to test if they follow the same data generating process. Nevertheless, the regression was able to provide meaningful insights regarding the association between variations in food waste and economic drivers.

Much is left to explain regarding the effect of Covid-19 pandemic and food waste. Future research may include a more detailed analysis of the impact of bouncing forward strategies. While data constrained us to use specific examples as indicators of the general attitude, future studies might build constructs for a more precise measurement of firms' resilience. Moreover, the investigation of differences among stages of the supply chain is a key topic for future research.

Supplementary Materials: The following are available online at https://www.mdpi.com/article/10 .3390/agronomy11061063/s1. Table S1: Variable coding.

Author Contributions: Conceptualization, C.R., F.D.M., and E.K.T.; empirical methodology, data curation, data analysis: F.D.M.; writing, Section 1: E.K.T., Sections 2.2 and 3: F.D.M., Sections 2.2, 4 and 5: C.R. All authors have read and agreed to the published version of the manuscript.

Funding: This research received no external funding.

Institutional Review Board Statement: Not applicable.

Informed Consent Statement: Study involved an online questionnaire and all participants agreed to the formal statement for privacy consensus. 
Data Availability Statement: Data supporting the reported results belong to an official dataset by J.R.C. Data are the proprietary of the European Commission.

Conflicts of Interest: The authors declare no conflict of interest.

\section{References}

1. Kalogiannidis, S.; Chatzitheodoridis, F.; Kontsas, S. An Eclectic Discussion of the Effects of COVID-19 Pandemic on the World Economy During the First Stage of the Spread. Int. J. Financ. Res. 2020, 11. [CrossRef]

2. Aday, S.; Aday, M.S. Impact of COVID-19 on the food supply chain. Food Qual. Saf. 2020, 4, 167-180. [CrossRef]

3. Laborde, D.; Martin, W.; Swinnen, J.; Vos, R. COVID-19 risks to global food security. Science 2020, 369, 500-502. [CrossRef]

4. Deaton, B.J.; Deaton, B.J. Food security and Canada's agricultural system challenged by COVID-19. Can. J. Agric. Econ. 2020, 68, 143-149. [CrossRef]

5. Swinnen, J.; McDermott, J. Covid-19 and Global Food Security. EuroChoices 2020, 19, 26-33. [CrossRef]

6. Hobbs, J.E. Food supply chains during the COVID-19 pandemic. Can. J. Agric. Econ. 2020, 68, 171-176. [CrossRef]

7. Garnett, P.; Doherty, B.; Heron, T. Vulnerability of the United Kingdom's food supply chains exposed by COVID-19. Nat. Food 2020, 1, 315-318. [CrossRef]

8. European Commission. Short-Term Outlook for EU Agricultural Markets in 2020; European Commission: Brussels, Belgium, 2020.

9. OECD. Food Supply Chains and COVID-19: Impacts and Policy Lessons: Policy Responses to Coronavirus (COVID-19); Organisation for Economic Cooperation and Development: Paris, France, 2020.

10. Gustavsson, J.; Cederberg, C.; Sonesson, U.; Van Otterdijk, R.; Meybeck, A. Global Food Losses and Food Waste-Extent, Causes and Prevention; Food and Agriculture Organization (FAO) of the United Nations: Rome, Italy, 2011.

11. FUSIONS. Estimates of European Food Waste Levels; IVL Swedish Environmental Research Institute: Stockholm, Sweden, 2020.

12. Thyberg, K.L.; Tonjes, D.J. Drivers of food waste and their implications for sustainable policy development. Resour. Conserv. Recy. 2016, 106, 110-123. [CrossRef]

13. Priefer, C.; Jörissen, J.; Bräutigam, K.R. Food waste prevention in Europe-A cause-driven approach to identify the most relevant leverage points for action. Resour. Conserv. Recy. 2016, 109, 155-165. [CrossRef]

14. Garnett, T. Three perspectives on sustainable food security: Efficiency, demand restraint, food system transformation. What role for life cycle assessment? J. Clean. Prod. 2014, 73, 10-18. [CrossRef]

15. Corrado, S.; Caldeira, C.; Eriksson, M.; Hanssen, O.J.; Hauser, H.E.; van Holsteijn, F.; Liu, G.; Östergren, K.; Parry, A.; Secondi, L.; et al. Food waste accounting methodologies: Challenges, opportunities, and further advancements. Glob. Food Secur. 2019, 20, 93-100. [CrossRef]

16. Garrone, P.; Melacini, M.; Perego, A.; Sert, S. Reducing food waste in food manufacturing companies. J. Clean. Prod. 2016, 137, 1076-1085. [CrossRef]

17. Amicarelli, V.; Bux, C. Food waste in Italian households during the Covid-19 pandemic: A self-reporting approach. Food Secur 2021, 13, 25-37. [CrossRef]

18. Roe, B.E.; Bender, K.; Qi, D. The impact of COVID-19 on consumer food waste. Appl. Econ. Perspect. Policy 2021, $43,401-411$. [CrossRef]

19. Jribi, S.; Ismail, H.B.; Doggui, D.; Debbabi, H. COVID-19 virus outbreak lockdown: What impacts on household food wastage? Environ. Dev. Sustain. 2020, 22, 3939-3955. [CrossRef]

20. Rodgers, R.F.; Lombardo, C.; Cerolini, S.; Franko, D.L.; Omori, M.; Linardon, J.; Guillaume, S.; Fischer, L.; Fuller-Tyszkiewicz, M "Waste not and stay at home" evidence of decreased food waste during the COVID-19 pandemic from the US and Italy. Appetite 2021, 160, 105110. [CrossRef] [PubMed]

21. Amicarelli, V.; Tricase, C.; Spada, A.; Bux, C. Households' Food Waste Behavior at Local Scale: A Cluster Analysis after the Covid-19 Lockdown. Sustainability 2021, 13, 3283. [CrossRef]

22. Kulikovskaja, V.; Aschemann-Witzel, J. Food waste avoidance actions in food retailing: The case of Denmark. J. Int. Food Agribus. Mark. 2017, 29, 328-345. [CrossRef]

23. European Commission. Preparatory Study on Food Waste Across EU 27; European Commission [DG ENV-Directorate C]; European Commission: Brussels, Belgium, 2010. [CrossRef]

24. Aulakh, J.; Regmi, A.; Fulton, J.R.; Alexander, C.E. Estimating post-harvest food losses: Developing a consistent global estimation framework. In Proceedings of the 2013 Annual Meeting, Washington, DC, USA, 4-6 August 2013; Agricultural and Applied Economics Association: Milwaukee, WI, USA, 2013.

25. Johnson, L.K.; Bloom, J.D.; Dunning, R.D.; Gunter, C.C.; Boyette, M.D.; Creamer, N.G. Farmer harvest decisions and vegetable loss in primary production. Agric. Syst. 2019, 176, 102672. [CrossRef]

26. Chalak, A.; Abou-Daher, C.; Chaaban, J.; Abiad, M.G. The global economic and regulatory determinants of household food waste generation: A cross-country analysis. Waste Manag. 2016, 48, 418-422. [CrossRef]

27. Secondi, L.; Principato, L.; Laureti, T. Household food waste behaviour in EU-27 countries: A multilevel analysis. Food Policy 2015, 56, 25-40. [CrossRef]

28. Parfitt, J.; Barthel, M.; Macnaughton, S. Food waste within food supply chains: Quantification and potential for change to 2050. Philos. Trans. R. Soc. Lond. Bbiol. Sci. 2010, 365, 3065-3081. [CrossRef] [PubMed] 
29. Canali, M.; Amani, P.; Aramyan, L.; Gheoldus, M.; Moates, G.; Östergren, K.; Silvennoinen, K.; Waldron, K.; Vittuari, M. Food waste drivers in Europe, from identification to possible interventions. Sustainability 2017, 9, 37. [CrossRef]

30. Raak, N.; Symmank, C.; Zahn, S.; Aschemann-Witzel, J.; Rohm, H. Processing-and product-related causes for food waste and implications for the food supply chain. Waste Manag. 2017, 61, 461-472. [CrossRef] [PubMed]

31. Silvennoinen, K.; Nisonen, S.; Pietiläinen, O. Food waste case study and monitoring developing in Finnish food services. Waste Manag. 2019, 97, 97-104. [CrossRef]

32. Bilska, B.; Tomaszewska, M.; Kołożyn-Krajewska, D. Managing the Risk of Food Waste in Foodservice Establishments. Sustainability 2020, 12, 2050. [CrossRef]

33. FAO. The State of Food and Agriculture 2019. Moving forward on Food Loss and Waste Reduction; Food and Agriculture Organisation: Rome, Italy, 2019.

34. Gunders, D. Wasted: How America is losing up to 40 percent of its food from farm to fork to landfill. NRDC 2012, 26, 1-26.

35. Mena, C.; Adenso-Diaz, B.; Yurt, O. The causes of food waste in the supplier-retailer interface: Evidences from the UK and Spain. Resour. Conserv. Recy. 2011, 55, 648-658. [CrossRef]

36. Kantor, L.S.; Lipton, K.; Manchester, A.; Oliveira, V. Estimating and addressing America's food losses. Food Rev./Natl. Food Rev. 1997, 20, 2-12.

37. Griffin, M.; Sobal, J.; Lyson, T.A. An analysis of a community food waste stream. Agric. Hum. Values 2009, 26, 67-81. [CrossRef]

38. Waarts, Y.R.; Eppink, M.; Oosterkamp, E.B.; Hiller, S.R.C.H.; Van Der Sluis, A.A.; Timmermans, T. Reducing Food Waste; Obstacles Experienced in Legislation and Regulations; LEI, Part of Wageningen UR: Wageningen, The Netherlands, 2011.

39. Adam, A. Drivers of Food Waste and Policy Responses to the Issue: The Role of Retailers in Food Supply Chains; Working Paper No. 59/2015; EconStor: Kiel, Germany, 2015.

40. Kaipia, R.; Dukovska-Popovska, I.; Loikkanen, L. Creating sustainable fresh food supply chains through waste reduction. Int. J. Phys. Distrib. Logist. Manag. 2013, 43, 262-276. [CrossRef]

41. Bajželj, B.; Quested, T.E.; Röös, E.; Swannell, R.P. Role Reducing Food Waste Resilient Food Systems. Ecosyst. Serv. 2020, 45, 101140. [CrossRef] [PubMed]

42. Halloran, A.; Clement, J.; Kornum, N.; Bucatariu, C.; Magid, J. Addressing food waste reduction in Denmark. Food Policy 2014, 49, 294-301. [CrossRef]

43. Goonan, S.; Mirosa, M.; Spence, H. Getting a taste for food waste: A mixed methods ethnographic study into hospital food waste before patient consumption conducted at three New Zealand foodservice facilities. J. Acad. Nutr. Diet. 2014, $114,63-71$. [CrossRef] [PubMed]

44. Yona, O.; Goldsmith, R.; Endevelt, R. Improved meals service and reduced food waste and costs in medical institutions resulting from employment of a food service dietitian-a case study. Isr. J. Health Policy Res. 2020, 9, 5. [CrossRef] [PubMed]

45. Rosenzweig, C.; Iglesius, A.; Yang, X.B.; Epstein, P.R.; Chivian, E. Climate change and extreme weather events-Implications for food production, plant diseases, and pests. Glob. Chang. Hum. Health 2001, 2, 90-104. [CrossRef]

46. Cranfield, J.A. Framing consumer food demand responses in a viral pandemic. Can. J. Agric. Econ. 2020, 68, 151-156. [CrossRef]

47. Gostin, L.O.; Wiley, L.F. Governmental public health powers during the COVID-19 pandemic: Stay-at-home orders, business closures, and travel restrictions. JAMA 2020, 323, 2137-2138. [CrossRef]

48. Ender, B.P. Collinerity Diagnostic. Statistical Computing and Consulting; UCLA Office of Academic Computing, distribution-date: 20101123; UCLA Department of Education: Los Angeles, CA, USA, 2010.

49. Greene, W.H. Econometric Analysis, 7th ed.; Pearson Education: Boston, FL, USA, 2012.

50. Long, M.H. Construct validity in SLA research: A response to Firth and Wagner. Mod. Lang. J. 1997, 81, 318-323. [CrossRef]

51. Long, J.S.; Freese, J. Regression Models for Categorical Dependent Variables Using Stata, 3rd ed.; Stata Press: College Station, TX, USA, 2006.

52. Bowen, H.P.; Wiersema, M.F. Modeling Limited Dependent Variables: Methods and Guidelines for Researchers in Strategic Management; Emerald Group Publishing Limited: Bingley, UK, 2004; Volume 1, pp. 87-134.

53. Pierce, M.; McManus, S.; Jessop, C.; John, A.; Hotopf, M.; Ford, T.; Hatch, S.; Wessely, S.; Abel, K.M. Says who? The significance of sampling in mental health surveys during COVID-19. Lancet Psychiatry 2020, 7, 567-568. [CrossRef]

54. Hlatshwako, T.G.; Shah, S.J.; Kosana, P.; Adebayo, E.; Hendriks, J.; Larsson, E.C.; Hensel, D.J.; Erausquin, J.T.; Marks, M.; Michielsen, K.; et al. Online health survey research during COVID-19. Lancet Digit. Health 2021, 3, e76-e77. [CrossRef]

55. Salari, N.; Hosseinian-Far, A.; Jalali, R.; Vaisi-Raygani, A.; Rasoulpoor, S.; Mohammadi, M.; Rasoulpoor, S.; Khaledi-Paveh, B. Prevalence of stress, anxiety, depression among the general population during the COVID-19 pandemic: A systematic review and meta-analysis. Glob. Health 2020, 16, 57. [CrossRef] [PubMed]

56. Gardner, B.L. The farm-retail price spread in a competitive food industry. Am. J. Agric. Econ. 1975, 57, 399-409. [CrossRef]

57. Darnhofer, I. Resilience and why it matters for farm management. Eur. Rev. Agric. Econ. 2014, 41, 461-484. [CrossRef] 